\title{
The Possibilities of Additive Manufacturing in Medical Use
}

\author{
D. SzABÓ
}

University of Debrecen, Faculty of Engineering, Department of Mechanical Engineering, szabo.daniel995@gmail.com

Abstract. Additive Manufacturing has been invented in 1981 at the University of Texas, and to this day it has grown to be the most versatile and promising manufacturing technology in the market, both the industry and health care system has noticed this. Additive Bio-Manufacturing (ABM) techniques, which can be used in health care, are highly in demand, and researches have been going on to make these technologies safer and even more versatile. For more utilization and versatility, special attention is required to develop new materials which can help in increasing the service life, bioactivity, cell growth along with the desired mechanical properties, and to find the right manufacturing parameters for creating optimal products. The aim of this review is to present the available main Additive Manufacturing technologies, and particularly the biomedical usability of Additive Manufacturing.

\section{Introduction}

Additive Manufacturing has been invented at the University of Texas in 1981 by Carl Deckard, Joe Beaman and Paul Forderhase with the invention of the Selective Laser Sintering process. This process used computer controlled laser beams for fusing a material powder layer by layer to build an object.

In the past 20 years, the technology of Additive Manufacturing has developed rapidly, and today the expression refers to more than one manufacturing method, like

- „Rapid Prototyping”

- „Solid free-form Fabrication”

- „Three Dimensional Printing”

The advantages of Additive Manufacturing [1, 2, 3]

- Higher degree of freedom for innovative design

- Structural complexity without added financial burdens, even in small sizes

- The potential elimination of tooling costs

- Direct manufacturing without molds

- Part integration reducing the number of subassemblies in compositions

- Low weight designs

- High rate of material usage, low waste rates 
- Economy friendly

The disadvantages of Additive Manufacturing [1, 2, 3]

- Slow building process

- High material costs

- Limited component size

- Dimensional inaccuracy

- The quality and stability of the used material powder

- Need of post processing to achieve the required qualities

- The possibility to calculate and plan residual stress

- High effort is required for application development and to find the right parameters for the manufacturing process

With the continous development of Additive Manufacturing, it expands to many fields of manufacturing. It fits perfectly into the chain of numerical design and manufacturing processes. In the past years, aerospace, automobile industry, and medical use were the key sectors of development.

With the help of Additive Manufacturing, we can build

- Prototypes

- Creative presentation pieces

- Customized everyday items

- Medical implants with unique properties

A cellular structure can also be produced by metal foaming, but the foaming process is hardly controllable and results in a random cellular structure, therefore it is not possible to manufacture and reproduce equal parts with this method. This means that it is not suitable for biomedical use, but it is excellent for other industries. There have been researches investigating metal foams at University of Debrecen's Department of Mechanical Engineering. [4, 5, 6, 7, 8, 9, 10, 11, 12] The results of these studies can be used in the analyzation and optimisation of the accuracy, quality and mechanical properties of parts produced with Additive Manufacturing.

\section{Plastic manufacturing}

There are three main types of Plastic Additive Manufacturing, laser based technologies, extrusion based technologies and JET technologies. These technologies differ in the way they create the product during the manufacturing process.

\subsection{Laser based technologies}

In laser based technologies first they design a model using a 3D software, possibly based on CT/MRI images (in case of biologic use). The 3D model is divided into 2 dimensional layers, where layer 
thickness is an important attribute. The sliced model is stored in .STL format. Models converted to this format can be processed and manufactured by the printing device layer by layer. [13]

Manufacturing technologies in this group work based on a similar principle. There is a manufacturing area, and a raw material storage area. There is a construction table in the manufacturing area, which gets lowered by an increment after the completion of each layer. The device moves fresh material from the material storage area into the manufacturing area, which then gets scanned and selectively fused by a laser beam. This process repeats until the part is ready.

Stereolithography (SLA), and Selective Laser Sintering (SLS) are the most widespread and commonly used laser based Additive Manufacturing technologies for plastic manufacturing.

\subsection{Extrusion based technologies}

In extrusion based technologies, two types of materials are used simultaneously. One material is used for building the desired part, the other one is used for building the supporting structure required during the manufacturing process. The supporting structure is removed after the part is finished. The building materials are supplied in the form of plastic wires from coils. To produce the parts, the plastic wire gets moved through a heated extrusion head, where it is half-liquified. The head precisely extrudes the molten materials in ultra-thin layers onto a base surface. The result of this process is a 3D model built up layer by layer. [14]

The most common extrusion based plastic Additive Manufacturing technology is Fused Deposition Modeling (FDM).

\subsection{JET technologies}

JET technologies were developed based on the inkjet printing process.

MultiJet Modeling (MJM) uses a plastic resin or casting wax for building parts, which solidifies when exposed to a light source. [15]

3 Dimensional Printing (3DP) deposits binder droplets onto a powder bed to stick powder molecules together and form a part layer by layer. [16]

\section{Metal manufacturing}

In case of Metal Additive Manufacturing, the two main parameters of the process are type of raw material, and type of power source. Metal Additive Manufacturing technologies can be divided into two main groups, Powder Bed Fusion based technologies, and Direct Energy Deposition based technologies. The two main groups can be further divided based on the type of energy source used. [17] 


\subsection{Powder Bed Fusion (PBF) based technologies}

In Powder Bed Fusion based technologies, every layer of powder gets fused selectively using an energy source, f.e. laser. These are the most promising Additive Manufacturing technologies for producing small sized, complex metallic parts in low volume. [18]

Selective Laser Melting (SLM), Direct Metal Laser Sintering (DMLS), and Electron Beam Melting (EBM) are the main Powder Bed Fusion based technologies.

\subsection{Direct Energy Deposition (DED) based technologies}

Direct Energy Deposition is a complex manufacturing process, which is mostly used for repairing, or adding new features to an existing part. Direct Energy Deposition is less widespread in Metal Additive Manufacturing, mainly due to lower precision and required post processing. The most widespread repairing procedures are Cold Gas Spraying, High Velocity Oxygen Fuel Spraying, and Laser Metal Deposition. [19]

A typical DED machine consists of a nozzle fixed onto a multi axle arm, and a laser or electron beam power source. The arm deposits the material onto the designated area, where the power source solidifies it. This process can also be used for working with polymers and ceramics, but its main area of application is for metals in the form of powder or wire. [20]

With the usage of DED based technologies, larger sized parts can be manufactured.

Laser Engineered Net Shaping (LENS), and Direct Metal Deposition (DMD) are the main DED based technologies there are to mention.

\section{The biomedical use of Additive Manufacturing}

In biomedical implants, interconnected porosity is a key property. The porosity has to be between 20 and 50 volume percent for optimal bone ingrowth. [21] The build material of the implant must not be magnetic, and has to be of high density. It has to have high specific strength and stiffness while being low weight, durable, compatible with blood, capable of bone ingrowth, and bioactive.

Most implants are subject to loads, which can be static or cyclic. This poses the need to choose a material which is both strong and flexible at once, therefore can withstand cyclic loads, because in the human body, cyclic loads occur.

In case of orthopaedic implants, the materials need to have outstanding toughness, flexibility, stiffness, strength, and resistance to fracture. In case of whole joint replacement, the material has to be resistant to wear, to prevent debris formation due to friction. It is also needed to be resistant to corrosion, which protects both the implant and the organism. Heat resistance and biocompatibility are also required key properties. [22] 
Biocompatibility means that the biomaterial can fulfil its purpose without causing any unwanted local or system - scale effects, whilst causing the best possible cellular or histological reaction in the patient's body in the given situation. [23]

\subsection{Medical applications}

The organ transplantation sector is troubled with difficulties, and the JET technology based on 3D tissue forming offers a possible solution for the printing of organs. There are researches which define organ printing as a computer aided Rapid Prototyping 3D printing process, which is based on the deposition of cells or cell structures into a gel. In this gel, the printed construction matures successively into a vascularized, perfused living tissue or organ. Bio printing is a process desired by hospitals for printing tissues and organs. There are several biocompatible materials available, f.e. curable synthetic polymers, synthetic gels, and naturally derived hydrogels.

3D Printing was first used with high success rates in the area of prostheses. It is possible to reproduce and 3D print the skull anatomy of patients for the planning of surgeries. It is also possible to improve the fixation of hip prostheses with 3D printable porous structures, which can increase their life expectancy, and with such implant it is possible to restore the original biomechanical properties of the hip. [24]

A company specialised for implants fabricated by Additive Manufacturing, Alphaform, manufactured a hip implant from titanium alloy with an EOSINT M280 machine. The implant was made for a Croatian patient, who suffered from an aggressive type of bone cancer, which destroyed a part of his hip bone, therefore the only possible solution was the reconstruction of the whole hip bone. [25]

To keep the implant's weight to a minimum value, the engineers added holes into the structure. A structure like this could only be manufactured with the usage of Additive Manufacturing. The challenge in the integration of the holes was finding the right mixture of structural stability and weight reduction, because the implant had to withstand high physical stresses. The process from the drawing of the first CAD models to the manufacturing of the implant took 6 weeks. [26] 


\subsection{The schematic of implant fabrication [27]}

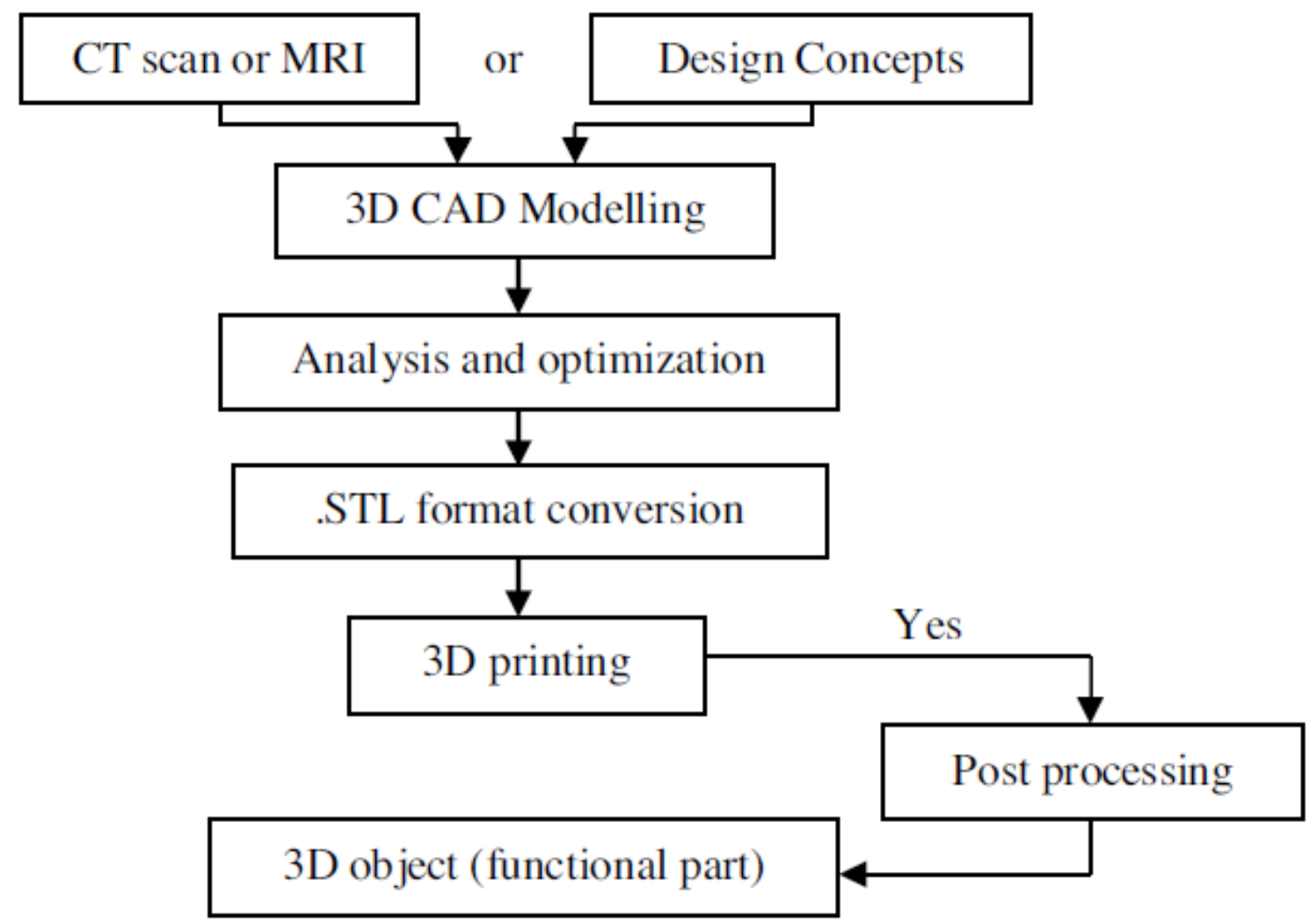

Figure 1. Schematic of implant fabrication [27]

\section{References}

[1] P. Krawczak (2015) Additive Manufacturing of plastic and polymer composite parts - promises and challenges of 3D printing. eXPRESS Polymer Letters. 9 (11) 959.

[2] T. Duda - L. V. Raghavan (2016) 3D Metal Printing Technology. IFAC-PapersOnLine 49-29 pp. 103-110

[3] T. S. Kumar - P. Sarang - A. Sanat - B. Santosh M. (2015) Selection of selective laser sintering materials for different applications. Rapid Prototyping Journal. Bradford 21 (6) pp. 630-648.

[4] T. Mankovits (2018) Numerical analysis of unit cell models for orthopedic applications. IOP Conference Series: Materials Science and Engineering. 393 Paper: 012019

[5] T. Mankovits - T. A. Varga - S. Manó - I. Kocsis (2018) Compressive Response Determination of Closed-Cell Aluminium Foam and Linear-Elastic Finite Element Simulation of $\mu$ CT-Based Directly Reconstructed Geometrical Models. Strojniski Vestnik-Journal of Mechanical Engineering. 64 (2) pp. 105-113.

[6] T. A. Varga - T. Mankovits (2018) Fémhabok elemzése CT felvételek alapján. Acta Materiala Transylvanica / Anyagtudományi Közlemények. 1 (1) pp. 57-60.

[7] T. A. Varga - T. Mankovits (2017) Fémhabok képi elemzése és geometriai modellezése = Visual analysis and geometric modeling of metal foams. International Journal of Engineering and Management Sciences / Műszaki És Menedzsment Tudományi Közlemények. 2 (1) pp. 89-92. 
[8] T. A. Varga - T. Mankovits (2016) Fémhabstruktúrák elemzése és geometriai modellezése. International Journal of Engineering and Management Sciences / Múszaki És Menedzsment Tudományi Közlemények. 1 (2) pp. 145-152.

[9] T. A. Varga - I. Kozma - I Budai - T. Mankovits (2015) Modelling Questions Of Metal Foams; In: S. Bodzás - T. Mankovits (szerk.) Proceedings of the 3rd International Scientific Conference on Advances in Mechanical Engineering (ISCAME 2015) Debrecen, Magyarország: University of Debrecen Faculty of Engineering. pp. 258-262.,5 p.

[10] T. Mankovits - I. Budai - G. Balogh - A. Gábora - I. Kozma - T. Varga - S. Manó - I. Kocsis (2014) Structural analysis and its statistical evaluation of a closed-cell metal foam. International Review Of Applied Sciences and Engineering 5 (2) pp. 135-143.

[11] G. Balogh - L. Tóth - T. Mankovits - S. Manó (2013) Titán habok gyártási technológiájának áttekintése = Manufacturing technologies of titanium foam review In: T. Mankovits (szerk.) Proceedings of the 1st international scientific conference on advances in mechanical engineering (ISCAME 2013) : 10-11 October 2013, Debrecen, Hungary: Debreceni Egyetem Műszaki Kar. pp. 8-12.

[12] S. Manó - L. Tóth - T. Mankovits - G. Balogh - I. Soltész - Z. Csernátony (2013) Fémhabokból készült implantátumok = Implants made from metal foams. In: T. Mankovits (szerk.) Proceedings of the 1st international scientific conference on advances in mechanical engineering (ISCAME 2013): 10-11 October 2013, Debrecen, Hungary: Debreceni Egyetem Műszaki Kar. pp. 114-119.

[13] M.S.I. Ruiz - M.A.N. Frías - R.M. Rider - A.P. Guillén - A.G. Rangel (2015) Fundamentals of stereolithography, an useful tool for diagnosis in dentistry. Int J Dent Sci. 17(1)

[14] S. Upcraft - R. Fletcher (2003) The rapid prototyping technologies. Assem Autom. 23 pp. 318-30.

[15] What is MJP (Multijet Printing)? https://www.3dsystems.com/resources/informationguides/multi-jet-printing/mjp (Downloaded 2018.11)

[16] E.M. Sachs - J.S. Haggerty - M.J. Cima (1993) Three-dimensional printing techniques; US Patent, 204,055. US Patent and Trademark Office, Massachusetts Institute of Technology

[17] S. Singh - S. Ramakrishna - R. Singh (2017) Material issues in additive manufacturing - A review. Journal of Manufacturing Processes. 25 pp. 185-200

[18] E.O. Olakanmi - R.F. Cochrane - K.W. Dalgarno (2015) A review on selective laser sintering/melting (SLS/SLM) of aluminium alloy powders: Processing, microstructure, and properties. Progress in Materials Science. 74 pp. 401-477

[19] T. Duda - L. V. Raghavan(2016) 3D Metal Printing Technology. IFAC-PapersOnLine. 49-29 pp. 103-110

[20] About Additive Manufacturing:

http://www.lboro.ac.uk/research/amrg/about/

the7categoriesofadditivemanufacturing/directedenergydeposition/

(Downloaded 2018.11)

[21] J.Y. Wong - J.D. Bronzino (2007) Biomaterials. CRC Press, Boca Raton.

[22] L. Xiang - W. Chengtao - Z. Wenguang - L. Yuanchao (2010) Fabrication and compressive properties of Ti6Al4V implant with honeycomb-like structure for biomedical applications. Rapid Prototyping Journal. 16 (1) pp. 44-49.

[23] M. Vaezi - H. Seitz - S. Yang (2013) A review on 3D micro-additive manufacturing technologies. International Journal of Advanced Manufacturing Technology. 67 pp. 1721-1754 
International Journal of Engineering and Management Sciences (IJEMS) Vol. 4. (2019). No. 1

DOI: 10.21791/IJEMS.2019.1.31.

[24] J. Gardan (2016) Additive manufacturing technologies: State of the art and trends. International Journal of Production Research. 54 (10) pp. 3118-3132

[25] I. van Zyl - I. Yadroitsava - I. Yadroitsev (2016) Residual stress in Ti6Al4V objects produced by Direct Metal Laser Sintering. South African Journal of Industrial Engineering. 27(4), pp 134-141.

[26] https://www.eos.info (Downloaded 2018.11)

[27] C.M.B. Ho - S.H. Ng - Y.J. Yoon (2015) A review on 3d printed bioimplants. Int J Precis EngManuf. 16(5) pp. 1035-46. 